\title{
METAKOGNISI DALAM PEMBELAJARAN MATEMATIKA
}

\section{Oleh}

\section{Rika Ulandari}

\section{Rikaulandari988@gmail.com}

\begin{abstract}
Abstrak
Pada proses pembelajaran terkadang terdapat kesalahan konsep pada informasi yang diperoleh peserta didik yang telah disampaikan oleh guru. Terkait dengan hal tersebut, metakognisi dapat memantau tahap berfikir peserta didik sehingga dapat menjelaskan cara berpikir dan hasil berpikirnya. Dalam proses pembelajaran, metakognisi mempunyai peran penting khususnya dalam pemecahan masalah matematika. Metakognisi sebagai proses seseorang berpikir tentang berpikir dalam rangka membangun strategi untuk memecahkan masalah. Metakognisi dapat dilihat dari aktivitas seperti merencanakan bagaimana pendekatan yang diberikan dalam tugas-tugas pembelajaran, memonitor kemampuan dan mengevaluasi rencana rencana dalam rangka melaksanakan tugas. Beberapa langakah untuk mengembangkan metakognisi diantaranya: mengidentifikasi "apa yang kau ketahui”, berbicara tentang berpikir, membuat jurnal berpikir, membuat perencanaan dan regulasi diri, melaporkan kembali proses berpikir, dan evaluasi diri. Semua siswa telah menggunakan strategi metakognisi dalam pembelajaran matematika, dengan kategori yang bervariasi dan secara umum berkategori jarang. Strategi yang paling tinggi atau sering digunakan oleh siswa secara umum adalah tutor sebaya, dan yang paling jarang digunakan adalah Evaluating the way of thinking and acting. Pengembangan kemampuan metakognisi siswa dalam pembelajaran matematika dapat dilakukan melalui pembiasaan berpikir, ini perlu dilakukan terus menerus dan berkelanjutan untuk selanjutnya diteliti efektivitasnya. Hal demikian tidak selalu mudah dilakukan. Proses penemuan konsep tidak serta-merta dapat dilakukan siswa. Demikian juga aktivitas metakognisi siswa juga tidak selalu terjadi dengan mudah. Oleh karena itu bimbingan guru merupakan hal yang esensial.

Kata kunci : Metakognisi, Strategi Metakognisi, Pengembangan Metakognisi Dalam Pembelajaran Matematika.
\end{abstract}




\section{A. Latar Belakang}

Pada umumnya matematika dipandang sebagai bidang studi yang kaku, simbolik dan jauh dari realita kehidupan sehari-hari. Pandangan tersebut berakibat pada adanya asumsi bahwa untuk mempelajari matematika, seorang siswa harus berfikir serius, abstrak, dan selalu menghapal rumus. Oleh karena itu, tidak jarang ada anggapan bahwa mata pelajaran matematika merupakan mata pelajaran yang sulit ,susah dipahami, dan membosankan bahkan bagi sebagian siswa menganggap matematika merupakan hal yang menakutkan, sehingga mereka cenderung menghindari mata pelajaran itu.

Pada proses pembelajaran terkadang terdapat kesalahan konsep pada informasi yang diperoleh peserta didik yang telah disampaikan oleh guru. Terkait dengan hal tersebut, metakognisi dapat memantau tahap berfikir peserta didik sehingga dapat menjelaskan cara berpikir dan hasil berpikirnya.

Dalam proses pembelajaran, metakognisi mempunyai peran penting khususnya dalam pemecahan masalah matematika. Untuk memperoleh hasil dan manfaat yang optimal dalam memecahkan masalah matematika, harus dilakukan melalui langkahlangkah pemecahan yang terorganisir dengan baik. Salah satu bentuk pengorganisasian pemecahan masalah matematika adalah seperti yang dikemukakan oleh polya (1981) terdiri dari (1) memahami masalah, (2) membuat rencana penyelesaian (3) melaksanakan rencana penyelesaian, dan (4) memeriksa kembali solusi yang telah diselesaikan. Melalui langkah-langkah pemecahan masalah yang sistematis dan hasilnya tidak saja berupa pemecahan yang benar, tetapi juga terbentuknya pola piker yang terstruktur dengan baik pada diri seseorang pada saat menghadapi masalah yang harus dipecahkan.

Strategi metakognisi mengontrol pikirannya dengan merancang, memantau dan menilai apa yang dipelajari. Oleh sebab itu dalam menggunakan strategi metakognisi siswa dapat mengontrol pembelajarannya seperti merancang apa yang hendak dipelajari, memantau kemajuan pembelajaran diri, dan menilai apa yang dipelajari. Apabila siswa menggunakan kemampuan metakognisisnya dengan baik, maka siswa tersebut akan mudah dalam memecahkan masalah matematika.

Pembahasan yang akan dibahas dalam makalah ini adalah bagaimana mengembangkan metakognisi pebelajar dalam pembelajaran matematika. Pengembangan dimaksud adalah proses pemanfaatan berbagai strategi yang dapat 
mengaktifkan metakognisi pebelajar pada saat berlangsungnya proses pembelajaran khususnya pada pembelajaran matematika.

\section{A. Rumusan Masalah}

1. Apa yang dimaksud dengan Metakognisi?

2. Bagaimana Strategi Pengembangan Metakognisi?

3. Bagaimana Pengembanagan kemampuan Metakognisi siswa Dalam Pembelajaran Matematika?

\section{B. Tujuan Masalah}

Tujuan dari penulisan makalah ini untuk mengetahui pengertian, strategi, dan kemamppuan metekognisi siswa dalam pembelajaran matematika. Selain itu, penulisan makalah ini juga bertujuan untuk memenuhi salah satu tugas mata kuliah Metodologi penelitian Pendidikan Matematika. 


\section{A. Pengertian Metakognisi}

Metakognisi merupakan istilah yang diperkenalkan Flavell tahun 1976. Flavell (Lioeet al./ 2006) menyatakan bahwa metakognisi merupakan kesadaran seseorang tentang proses kognitifnya dan kemandiriannya untuk mencapai tujuan tertentu. Secara lebih proses kognitifnya dan kemandiriannya untuk mencapai tujuan tertentu. Secara lebih rinci Biryukov (2003) mengemukakan bahwa konsep metakognisi merupakan dugaan pemikiran seseorang tentang pemikirannya yang meliputi pengetahuan metakognkitif (kesadaran seseorang tentang sesuattu yang diketahuinya), keterampilan metakognitif (kesadaran seseorang tentang sesuatu yang dilakukannya) dan pengalaman metakognitif (kesadaran seseorang tentang kemampuan kognitif yang dimilikinya). Misalnya siswa SMP mempelajari materi bilangan bulat, dia perlu meyadari pengetahuan yang dimilikinya tentang konsep dan sifat-sifat operasi hitung bilangan bulat yang telah diipelajarinya dari SD, mengetahui dan memahami prosedur operasi hitung bilangan bulat yang dilakukannya dan menyadari kemampuan yang dimilikinya untuk menyelesaikan masalah terkait bilangan bulat.

Metakognitif inilah yang dibutuhkan siswa untuk mengontrol aspek kognitifnya sehingga ketika siswa tersebut mendapatkan materi dari guru, maka materi itu akan mudah diserap (Amir, 2018). Jika hal tersebut terjadi, maka kecerdasan siswa akan terasah sehingga secara tidak langsung akan meningkatkan prestasi belajar siswa tersebut (Iskandar, 2016). ${ }^{1}$

Pengetahuan metakognitif memuat pengetahuan deklaratif (declarative knowledge), pengetahuan procedural (procedural knowledge), dan pengetahuan kondisional (conditional knowledge) (OLRC News, 2004). Pengetahuan deklaratif yaitu pengetahuan tentang diri sendiri sebagai pebelajar serta pengetahuan tentang strategi, keterampilan dan sumber-sumber belajar yang dibutuhkannya untuk keperluan belajar. Pengetahuan procedural yaitu pengetahuan tentang bagaimana menggunakan segala sesuatu yang telah diketahui dalam pengetahuan deklaratif dalam aktivitas belajarnya. Pengetahuan kondisional yaitu pengetahuan tentang bilamana menggunakan suatu prosedur, keterampilan, atau strategi dan bilamana hal-hal tersebut tidak digunakan,

\footnotetext{
${ }^{1}$ Nurjannah, "Siswa the Exploration of Metacognition of Mathematical Problem Solving Reviewed By," AULADUNA: Jurnal Pendidikan Dasar Islam 6, no. 1 (2019): 78-89.
} 
mengapa suatu prosedur berlangsung dan dalam kondisi yang bagaimana berlangsungnya, dan mengapa suatu prosedur lebih baik daripada prosedur-prosedur yang lain. Oleh karena itu pengetahuan metakognitif dianggap sebagai berpikir tingkat tinggi, karena melibatkan fungsi eksekutif yang lebih mengkoordinasikan perilaku pembelajaran. $\mathrm{s}^{2}$

Taccasu (2008) mendefinisikan metakognisi, yaitu bagian dari perencanaan, pemonitoringan, dan pengevaluasian proses belajar serta kesadaran dan pengontrolan proses belajar. Berdasarkan penjelasan tersebut, dapat disimpulkan bahwa metakognisi adalah suatu kesadaran siswa dalam menggunakan pemikirannya untuk merencanakan, mempertimbangkan, mengontrol, dan menilai terhadap proses kognitif yang dimilikinya.

Dikaitkan dengan pemecahan masalah,maka metakognisi juga berhubungan dengan cara berpikir siswa tentang berpikirnya sendiri dan kemampuan mereka dalam memilih strategi yang tepat untuk memecahkan masalah. Terlaksananya kemampuan metakognisi dalam pemecahan masalah merupakan salah satu factor menarik yang banyak diperhatikan oleh kalangan peneliti pendidikan. Ketika pemecahan masalah dilakukan dengan melibatkan kesadaran terhadap proses berpikir serta kemampuan pengaturan diri, sehingga memungkinkan pemahaman yang kuat disertai alasan yang logis. Pemahaman seperti ini merupakan sesuatu yang selalu ditekankan ketika berlangsungnya pembelajaran matematika di semua tingkatan pendidikan, karena kesesuaiannya yang kuat dengan pola berpikir matematika.

Hal yang paling penting dalam pembelajaran yang harus diperhatikan adalah proses, bukan semata-mata hasil akhir. Olehnya itu, proses pembelajaran tidak dapat dianggap enteng karena didalamnya terdapat nilai yang sangat penting yang akan mencerminkan kemampuan siswa. Hal ini berlaku pula pada proses pemecahan masalah. Karena pemecahan masalah tidak lepas dari prosesnya yang memerlukan pemikiran yang ekstra (Nurgiyantoro, 2010).

Dalam pembelajaran matematika, pertanyaan atau masalah yang dihadapkan kepada siswa biasanya dalam bentuk soal cerita (Hidayah, 2016) (Nurjannah, 2019).

\footnotetext{
${ }^{2}$ Atma Murni, "Pembelajaran Matematika Dengan Pendekatan Metakognitif Berbasis Masalah Kontekstual," Pembelajaran Matematika Dengan Pendekatan....., no. November (2010): 518-27.
} 
Sebagian besar ahli Pendidikan Matematika menyatakan bahwa masalah merupakan pertanyaan yang harus dijawab atau direspon, tetapi mereka juga menyatakan bahwa tidak semua pertanyaan otomatis akan menjadi masalah (Nurjannah, 2020). Suatu pertanyaan akan menjadi masalah hanya jika pertanyaan itu menunjukkan adanya suatu tantangan (challenge) yang tidak dapat dipecahkan dengan suatu prosedur rutin (routine procedure) yang sudah diketahui oleh pemecah masalah (Dhurori, A \& Markaban, $2010 .^{3}$

Kemampuan pemecahan masalah adalah sebuah kompetensi yang dimiliki seseorang dalam proses menyelesaikan masalah untuk menemukan solusi melalui tahapan-tahapan pemecahan masalah (Polya, 1981, p.11; (Gd. Gunantara, Md Suarjana, 2014). Pada tahapan pemecahan masalah meliputi memahami masalah, merencanakan pemecahan masalah, melaksanakan pemecahan masalah, dan memeriksa kembali (Polya, 2004, p.5-6; (Slavin, 2006); (Walle, 2007); (Santrock, 2011) Santrock, 2011, p.317-318); Yimer \& Ellerton, 2010, p.245-246). ${ }^{4}$

Lee dan Baylor (2006) menyatakan bahwa "metacognition as the ability to understand and monitor one's activities". Pernyataan ini menekankan metakognisi sebagai kemampuan untuk mengetahui dan memantau kegiatan berpikir seseorang, sehingga proses metakognisi dari masing-masing orang akan berbeda menurut kemampuannya. Perbedaan kemampuan matematika memungkinkan adanya perbedaan proses metakognisi yang dilakukan siswa ketika melakukan pemecahan masalah matematika, namun tidak semua siswa melibatkan proses metakognisi dalam kegiatan pemecahan masalah sehingga proses metakognisi dari masing-masing orang akan berbeda menurut kemampuannya. Perbedaan kemampuan matematika memungkinkan adanya perbedaan proses metakognisi yang dilakukan siswa ketika melakukan pemecahan masalahnya. ${ }^{5}$

\footnotetext{
${ }^{3}$ Nurjannah et al., "Analisis Kesalahan Siswa Dalam Memecahkan Masalah Pisa Ditinjau Dari Gender," JTMT : Jurnal Tadris Matematika 1, no. 2 (2020): 1-8.

${ }^{4}$ Fitriani, "Kemampuan Pemecahan Masalah Siswa Smp," JTMT: Journal Tadris Matematika 01, no. 01 (2019): 25-30, http://journal.iaimsinjai.ac.id/index.php/Jtm/article/view/393.

${ }^{5}$ Nurhayati, Agung Hartoyo, and Hamdani, "Kemampuan Metakognisi Siswa Dalam Pemecahan Masalah Pada Materi Bangun Datar Di Kelas VII SMP," Jurnal Pendidikan Dan Pembelajaran Untan Vol. 6, No (2017): 1-13.
} 
Menurut Imel (2002), metakognisi sangat diperlukan untuk kesuksesan belajar, karena dengan metakognisi memungkinkan siswa untuk mampu mengelola kecakapan kognisi dan mampu melihat (menemukan) kelemahannya yang akan diperbaiki dengan kecakapan kognisi berikutnya. Orang yang mampu melakukan suatu keterampilan tertentu dapat dikatakan mampu melakukan metakognisi, yakni berpikir tentang bagaimana melakukan keterampilan tersebut. Siswa dapat didorong untuk melakukan metakognisi dengan cara meningkatkan kesadaran mereka bahwa metakognisi diperlukan untuk meningkatkan prestasi akademik mereka. Hasil peneliitiannya menyatakan bahwa siswa yang melakukan metakognisi (metacognitively aware learners) berprestasi lebih baik dibandingkan dengan siswa umumnya yang tidak melakukan metakognisi, karena metakognisi memungkinkan siswa melakukan perencanaan, mengikuti perkembangan, dan memantau proses belajarnya. Penelitian Fauzi (2009) juga mengungkapkan bahwa kemampuan metakognisi memiliki peranan yang strategis untuk memecahkan masalah-masalah dalam pembelajaran matgematika. Siswa dapat sadar akan kemampuan metakognisinya, akan melaksanakan berpikir yang lebih baik dan strategis disbanding siswa yang tidak sadar. Proses berpikir dalam pemecahan masalah merupakan hal penting yang perlu mendapat perhatian para pendidik terutama untuk membantu siswa mengembangkan kemamppuannya dalam memecahkan masalah. ${ }^{6}$

NCREL (1995) mengidentifikasi proses metakognisi menjadi tiga kelompok.

1. Mengembangkan rencana tindakan dengan mengajukan pertanyaan-pertanyaan berikut.

a. Pengetahuan awal apakah yang akan menolong saya mengerjakan tugas-tugas?

b. Dengan cara apakah saya mengarahkan pikiran saya?

c. Pertama kali saya harus melakukan apa?

d. Mengapa saya membaca bagian ini?

\footnotetext{
${ }^{6}$ Tanti Novita, Wahyu Widada, and Saleh Haji, “Metakognisi Siswa Dalam Pemecahan Masalah Matematika Siswa SMA Dalam Pembelajaran Matematika Berorientasi Etnomatematika Rejang Lebong," Jurnal Pendidikan Matematika Raflesia 3, no. 1 (2018): 41-54, https://ejournal.unib.ac.id/index.php/jpmr.
} 
e. Berapa lama saya menyelesaikan tugas ini?

2. Memantau rencana tindakan, meliputi pertanyaan-pertanyaan berikut.

a. Bagaimana saya melakukan tindakan?

b. Apakah saya berada pada jalur yang benar? c. Bagaimana seharus nya saya melakukan?

d. Informasi apakah yang penting untuk diingat?

e. Haruskah saya melakukan dengan cara berbeda?

f. Haruskah saya menyesuaikan langkah-langkah tindakan dengan tingkat kesukaran?

g. Jika tidak memahami, apakah yang perlu dilakukan?

3. Mengevaluasi rencana tindakan, meliputi pertanyaan-pertanyaan berikut.

a. Seberapa baik saya telah melakukan tindakan?

b. Apakah cara berpikir saya menghasilkan lebih banyak atau kurang sesuai dengan harapan saya/

c. Apakah saya telah melakukan secara berbeda?

d. Bagaimana saya menerapkan cara berpikir ini terhadap masalah yang lain?

e. Apakah saya perlu kembali mengerjakan tugas ini untuk mengisi kekosongan pemahaman saya? ${ }^{7}$

Berdasarkan beberapa pendapat para ahli tentang pengetahuan metakognisi, maka pengetahuan metakognisi yang dimaksud adalah pengetahuan tentang diri sendiri termasuk kesadaran berpikir seseorang tentang proses berpikirnya sendiri serta kesadaran tentang strategi berpikir yang digunakan dalam memecahkan masalah.

\footnotetext{
${ }^{7}$ Atma Murni, "Pembelajaran Matematika Dengan Pendekatan Metakognitif Berbasis Masalah Kontekstual."
} 
Metakognisi adalah kesadaran seseorang terhadap proses dan hasil berpikirnya, dalam mengembangkan perencanaan, memonitor pelaksanaan dan mengevaluasi suatu tindakan. Jadi dengan metakognisis seseorang akan "tahu yang diketahui dan tahu yang kamu tidak ketahui".

\section{B. Strategi Menumbuhkan Metakognitif Dalam Pembelajaran Matematika}

Beberapa aspek metakognitif dapat dikembangkan menggunakan strategi pengembangan metakognitif, misalnya penyelesaian masalah secara berpasangan (Pair Problem solving). Dalam Dalam pelaksanaannya satu siswa berbicara mengenai masalah tersebut, menguraikan proses berpikirnya, pasangannya mendengar dan menanyakan pertanyaan untuk membantu mengklarifikasikan pemikirannya. Pasangan kolaborasi ini disebut oleh Luis (2006) sebagai Thinker and Listener. (Luis, 2006) mengemukakan bahwa setting kelompok kecil dapat memunculkan pengungkapan katakata siswa secara spontan dan memungkinkan mereka untuk meningkatkan idenya melalui pengujian yang bersifat kritis. Berdasarkan pemaparan di atas, penulis merangkum beberapa strategi metakognitif yang dikembangkan dalam angket penggunaan strategi metakognitif dalam penelitian ini. ${ }^{8}$

Kualitas belajar murid dan lulusannya banyak ditentukan oleh keberhasilan seorang guru dalam mengelola kelas. Sehebat apa pun rencana dan tujuan yang ingin dicapai di atas kertas semuanya akan ditentukan dalam ruangan ukuran 6x8 meter (kelas). Pengelolaan kelas dalam bahasa Inggris diistilahkan sebagai classroom management. Ini berarti, istilah pengelolaan identik dengan manajemen. Pengertian pengelolaan atau manajemen pada umumnya, yaitu kegiatan-kegiatan meliputi perencanaan, pengorganisasian, pengarahan, pengkoordinasian, pengawasan, dan penilaian untuk mencapai tujuan. ${ }^{9}$

Penyampaian materi matematika dalam pembelajaran matematika dalam upaya mencapai kompetensi tertentu dapat dilakukan antara lain melalui cara-cara berikut.

\footnotetext{
${ }^{8}$ Amir Zubaidah, "Strategi Metakognitif Dalam Pembelajaran Matematika," Jurnal Penelitian Dan Pembelajaran Matematika 10, no. 1 (2017), https://doi.org/10.30870/jppm.v10i1.1198.

9 Diarti Andra Ningsih, "Guru Sebagai Manajer Kelas" 1, no. 1 (2019): 1-2.
} 
1. Guru menggunakan bahasa yang bersahabat dan dapat membantu merangsang berpikirnya siswa tentang materi matematika yang disampaikan. Penyampaian materi matematika secara realistik dan nyata dalam kehidupan siswa.

2. Guru mengajukan pertanyaan-pertanyaan yang merangsang metakognisi siswa. Misalnya: Setujukah kamu dengan pernyataan tersebut? Berikan alasan setuju/tidak setuju. Bagaimana penggunaan rumus ini dalam kehidupanmu?

Metakognisi dapat diwujudkan dengan mengajukan pertanyaan pada diri sendiri sehingga dapat mengetahui proses kognitif sendiri dan aktivitas kognitif yang dilakukan. Sebagaimana Huitt (1997) mengemukakan bahwa metakognisi mencakup kemampuan seseorang dalam bertanya dan menjawab beberapa tipe pertanyaan berkaitan dengan tugas yang dihadapi. Pertanyaan-pertanyaan tersebut adalah sebagai berikut: (1) apa yang saya ketahui tentang materi, topik, atau masalah ini?; (2) tahukah saya apa yang dibutuhkan untuk mengetahuinya?; (3) tahukah saya dimana dapat memperoleh informasi atau pengetahuan?; (4) berapa lama waktu yang dibutuhkan untuk mempelajarinya?; (5) strategi-strategi atau taktik-taktik apa yang dapat digunakan untuk mempelajarinya?; (6) dapatkah saya pahami dengan hanya mendengar, membaca, atau melihat?; (7) akankah saya tahu jika saya mempelajarinya secara cepat?; (8) bagaimana saya dapat membuat sedikit kesalahan jika saya melakukan sesuatu?

Penggunaan metode, strategi mengajar dan pendekatan oleh guru sangat menentukan kegiatan belajar siswa, serta penggunaan alat bantu peraga pelajaran dan media pembelajaran yang ada (Wibowo, 2012). Metode dan pendekatan pengajaran matematika sangat banyak meliputi metode ceramah, demonstrasi, tanya jawab, pemberian tugas, diskusi, inquiry dan lain-lain. Penggunaan metode-metode tersebut disesuaikan dengan materi yang akan disampaikan, karakteristik siswa, serta keberadaan lingkungan tempat siswa belajar (Rahmiati \& Pianda, 2018).

Strategi yang dapat dilakukan guru dalam mengembangkan metakognisi siswa melalui kegiatan pembelajaran menurut (Taccasu Project, 2008) adalah sebagai berikut.

1. Membantu siswa dalam mengembangkan strategi belajar dengan cara berikut.

a. Mendorong siswa untuk memonitor proses belajar dan berpikirnya. 
b. Membimbing siswa dalam mengembangkan strategi-strategi belajar yang efektif.

c. Meminta siswa untuk membuat prediksi tentang informasi yang akan muncul atau disajikan berikutnya berdasarkan apa yang mereka telah baca atau pelajari.

d. Membimbing siswa untuk mengembangkan kebiasaan bertanya.

e. Menunjukkan kepada siswa bagaimana teknik mentransfer pengetahuan, sikapsikap, nilai-nilai, keterampilan-keterampilan dari suatu situasi ke situasi yang lain.

2. Membimbing siswa dalam mengembangkan kebiasaan yang baik dengan cara berikut.

a. Pengembangan kebiasaan mengelola diri sendiri

Kebiasaan mengelola diri sendiri dapat dilakukan dengan: mengidentifikasi gaya belajar yang paling cocok untuk diri sendiri (visual, auditif, kinestetik, deduktif, atau induktif); (2) memonitor dan meningkatkan kemampuan belajar (membaca, menulis, mendengarkan, mengelola waktu, dan memecahkan masalah); (3) memanfaatkan lingkungan belajar secara variatif (di kelas dengan ceramah, diskusi, penugasan, praktik di laboratorium, belajar kelompok, dsb).

b. Mengembangkan kebiasaan untuk berpikir positif

Kebiasaan berpikir positif dikembangkan dengan: (1) meningkatkan rasa percaya diri (self-confidence) dan rasa harga diri (self-esteem); dan (2) mengidentifikasi tujuan belajar dan menikmati aktivitas belajar.

c. Mengembangkan kebiasaan untuk berpikir secara hirarkis

Kebiasaan untuk berpikir secara hirarkis dikembangkan dengan: (1) membuat keputusan dan memecahkan masalah; dan (2) memadukan dan menciptakan hubungan-hubungan konsep-konsep yang baru.

d. Mengembangkan kebiasaan untuk bertanya

Kebiasaan bertanya dikembangkan dengan : (1) mengidentifikasi ide-ide atau konsep-konsep utama dan bukti-bukti pendukung; (2) membangkitkan minat dan motivasi; dan (3) memusatkan perhatian dan daya ingat. 
Blakey dan Spence (1990) menyatakan bahwa untuk mengembangkan perilaku metakognitif dapat dilakukan enam strategi berikut.

1. Mengidentifikasi "apa yang diketahui" dan "apa yang tidak diketahui

2. Menceritakan tentang pemikiran

3. Membuat catatan pemikiran

4. Merencanakan dan melakukan pengaturan diri

5. Mengontrol proses berpikir

6. Evaluasi Diri. ${ }^{10}$

Dari Uraian di atas, dapat disimpulkan bahwa semua siswa telah menggunakan strategi metakognisi dalam pembelajaran matematika, dengan kategori yang bervariasi dan secara umum berkategori jarang. Strategi yang paling tinggi atau sering digunakan oleh siswa secara umum adalah tutor sebaya, dan yang paling jarang digunakan adalah Evaluating the way of thinking and acting.

\section{C. pengembangan Metakognisi dalam Pembelajaran Matematika}

Metakognisi siswa melibatkan pengetahuan dan kesadaran siswa tentang aktivitas kognitifnya sendiri atau segala sesuatu yang berhubungan dengan aktivitas kognitifnya. Blakey \& Spence (1990) mengemukakan langkah-langkah untuk meningkatkan metakognisi, yakni:

a. Mengidentifikasi "apa yang kau ketahui" dan "apa yang kau tidak ketahui"

Memulai aktivitas pengamatan, siswa perlu membuat keputusan yang disadari tentang pengetahuan mereka. Pertama-tama siswa menulis " apa yang sudah saya ketahui tentang ...." dan "apa yang ingin saya pelajari tentang ..." Dengan menyelidiki suatu topik, siswa akan menverifikasi, mengklarifikasi dan mengembangkan, atau mengubah pernyataan awal mereka dengan informasi yang akurat.

b. Berbicara tentang berpikir (talking about thinking)

\footnotetext{
${ }^{10}$ Atma Murni, "Pembelajaran Matematika Dengan Pendekatan Metakognitif Berbasis Masalah Kontekstual."
} 
Selama membuat perencanaan dan memecahkan masalah, guru boleh "menyuarakan pikiran", sehingga siswa dapat ikut mendemonstrasikan proses berpikir. Pemecahan masalah berpasangan merupakan strategi lain yang berguna pada langkah ini. Seorang siswa membicarakan sebuah masalah, mendeskripsikan proses berpikirnya, sedangkan pasangannya mendengarkan dan bertanya untuk membantu mengklarifikasi proses berpikir.

c. Membuat jurnal berpikir (keeping thinking journal)

Cara lain untuk mengembangkan metakognisi adalah melalui penggunaan jurnal atau catatan belajar. Jurnal ini berupa buku harian dimana setiap siswa merefleksi berpikir mereka, membuat catatan tentang kesadaran mereka terhadap kedwiartian (ambiguities) dan ketidakkonsistenan, dan komentar tentang bagaimana mereka berurusan/menghadapi kesulitan.

d. Membuat perencanaan dan regulasi diri

Siswa harus mulai bekerja meningkatkan responsibilitas untuk merencanakan dan meregulasi belajar mereka. Sulit bagi pebelajar menjadi orang yang mampu mengatur diri sendiri (self-directed) ketika belajar direncanakan dan dimonitori oleh orang lain.

e. Melaporkan kembali proses berpikir (debriefing thinking process)

Aktivitas terakhir adalah menfokuskan diskusi siswa pada proses berpikir untuk mengembangkan kesadaran tentang strategi-strategi yang dapat diaplikasikan pada situasi belajar yang lain. Metode tiga langkah dapat digunakan; Pertama: guru mengarahkan siswa untuk mereviu aktivitas, mengumpulkan data tentang proses berpikir; Kedua: kelompok mengklasifikasi ide-ide yang terkait, mengindentifikasi strategi yang digunakan; Ketiga: mereka mengevaluasi keberhasilan, membuang strategi-strategi yang tidak tepat, mengindentifikasi strategi yang dapat digunakan kemudian, dan mencari pendekatan alternatif yang menjanjikan.

f. Evaluasi diri (self-evaluation)

Mengarahkan pengalaman-pengalaman evaluasi diri dapat diawali melalui pertemuan individual dan daftar-daftar yang berfokus pada proses berpikir. Secara bertahap, evaluasi diri akan lebih banyak diaplikasikan secara independen. Upaya mengembangkan metakognisi siswa dapat digunakan dalam kegiatan pembelajaran dalam rangka pembentukan konsep atau dalam aktivitas pemecahan masalah. 
Komponen-komponen metakognisi tidak harus digunakan secara keseluruhan dan dalam urutan tertentu secara baku. Beberapa komponen tersebut dapat digunakan secara terpisah sesuai karakteristik masalah yang akan diselesaikan. Berikut diberikan contoh pemanfaatan metakognisi dalam aktivitas pemecahan masalah. ${ }^{11}$

Berpikir kreatif menjadi hal yang sangat dipertimbangkan sebagai keterampilan penting yang mungkin dan harus ditingkatkan oleh semua siswa (Mann, 2005). Hal ini sejalan dengan pendapat Beetlestone (2013) bahwa kemampuan berpikir kreatif dapat dan harus dikembangkan pada semua siswa. Akan tetapi, kemampuan tersebut tidak akan muncul begitu saja. Berpikir kreatif membutuhkan suatu konteks dimana individu melakukan persiapan yang didasarkan pada pengalaman-pengalaman sebelumnya yang signifikan untuk menghadapi

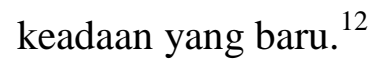

Pengembangan kemampuan metakognisi siswa dalam pembelajaran matematika dapat dilakukan melalui pembiasaan berpikir, ini perlu dilakukan terus menerus dan berkelanjutan untuk selanjutnya diteliti efektivitasnya. Hal demikian tidak selalu mudah dilakukan. Proses penemuan konsep tidak serta-merta dapat dilakukan siswa. Demikian juga aktivitas metakognisi siswa juga tidak selalu terjadi dengan mudah. Oleh karena itu bimbingan guru merupakan hal yang esensial.

\footnotetext{
${ }^{11}$ Nur Eva Sakiah, "METAKOGNISI DALAM PEMBELAJARAN MATEMATIKA :" 3 (2017): 24-35.

${ }^{12}$ Nurjannah, "Matematika Ditinjau Dari Adversity Quotient ( Aq )," JTMT (Jurnal Tadris Matematika) 01, no. 01 (2020): 7-13.
} 


\section{A. Kesimpulan}

Pada proses pembelajaran terkadang terdapat kesalahan konsep pada informasi yang diperoleh peserta didik yang telah disampaikan oleh guru. Terkait dengan hal tersebut, metakognisi dapat memantau tahap berfikir peserta didik sehingga dapat menjelaskan cara berpikir dan hasil berpikirnya. Dalam proses pembelajaran, metakognisi mempunyai peran penting khususnya dalam pemecahan masalah matematika. Untuk memperoleh hasil dan manfaat yang optimal dalam memecahkan masalah matematika, harus dilakukan melalui langkah-langkah pemecahan yang terorganisir dengan baik. Salah satu bentuk pengorganisasian pemecahan masalah matematika adalah seperti yang dikemukakan oleh polya (1981) terdiri dari (1) memahami masalah, (2) membuat rencana penyelesaian (3) melaksanakan rencana penyelesaian, dan (4) memeriksa kembali solusi yang telah diselesaikan. Melalui langkah-langkah pemecahan masalah yang sistematis dan hasilnya tidak saja berupa pemecahan yang benar, tetapi juga terbentuknya pola piker yang terstruktur dengan baik pada diri seseorang pada saat menghadapi masalah yang harus dipecahkan.

Metakognisi sebagai proses seseorang berpikir tentang berpikir dalam rangka membangun strategi untuk memecahkan masalah. Metakognisi dapat dilihat dari aktivitas seperti merencanakan bagaimana pendekatan yang diberikan dalam tugas-tugas pembelajaran, memonitor kemampuan dan mengevaluasi rencana rencana dalam rangka melaksanakan tugas. Beberapa langakah untuk mengembangkan metakognisi diantaranya: mengidentifikasi "apa yang kau ketahui", berbicara tentang berpikir, membuat jurnal berpikir, membuat perencanaan dan regulasi diri, melaporkan kembali proses berpikir, dan evaluasi diri. Metakognisi adalah kesadaran seseorang terhadap proses dan hasil berpikirnya, dalam mengembangkan perencanaan, memonitor pelaksanaan dan mengevaluasi suatu tindakan. Jadi dengan metakognisis seseorang akan "tahu yang diketahui dan tahu yang kamu tidak ketahui".

Semua siswa telah menggunakan strategi metakognisi dalam pembelajaran matematika, dengan kategori yang bervariasi dan secara umum berkategori jarang. Strategi yang paling tinggi atau sering digunakan oleh siswa secara umum adalah tutor sebaya, dan yang paling jarang digunakan adalah Evaluating the way of thinking and acting. 
Pengembangan kemampuan metakognisi siswa dalam pembelajaran matematika dapat dilakukan melalui pembiasaan berpikir, ini perlu dilakukan terus menerus dan berkelanjutan untuk selanjutnya diteliti efektivitasnya. Hal demikian tidak selalu mudah dilakukan. Proses penemuan konsep tidak serta-merta dapat dilakukan siswa. Demikian juga aktivitas metakognisi siswa juga tidak selalu terjadi dengan mudah. Oleh karena itu bimbingan guru merupakan hal yang esensial.

\section{B. Saran}

Dari pembahasan diatas, menunjukkan bahwa pemahaman tentang metakognisi dalam pembelajaran sangat diperlukan oleh seorang guru maupun siswa demi tercapainya tujuan pembelajaran yang baik, efektif, dan efisien. Selain itu hendaknya makalah ini dapat menjadi referensi untuk pembuatan makalah sejenis. 


\section{Daftar pustaka}

Nur Eva Zakiah. "METAKOGNISI DALAM PEMBELAJARAN MATEMATIKA :" 3 (2017): 24-35.

Diarti Andra Ningsih. “Guru Sebagai Manajer Kelas” 1, no. 1 (2019): 1-2.

Fitriani. "Kemampuan Pemecahan Masalah Siswa Smp.” JTMT: Journal Tadris Matematika 01, no. 01 (2019): 25-30.

http://journal.iaimsinjai.ac.id/index.php/Jtm/article/view/393.

Novita, Tanti, Wahyu Widada, and Saleh Haji. "Metakognisi Siswa Dalam Pemecahan Masalah Matematika Siswa SMA Dalam Pembelajaran Matematika Berorientasi Etnomatematika Rejang Lebong.” Jurnal Pendidikan Matematika Raflesia 3, no. 1 (2018): 41-54. https://ejournal.unib.ac.id/index.php/jpmr.

Nurhayati, Agung Hartoyo, and Hamdani. "Kemampuan Metakognisi Siswa Dalam Pemecahan Masalah Pada Materi Bangun Datar Di Kelas VII SMP.” Jurnal Pendidikan Dan Pembelajaran Untan Vol. 6, No (2017): 1-13.

Nurjannah. "Matematika Ditinjau Dari Adversity Quotient ( Aq ).” JTMT (Jurnal Tadris Matematika) 01, no. 01 (2020): 7-13.

—. "Siswa the Exploration of Metacognition of Mathematical Problem Solving Reviewed By.” AULADUNA: Jurnal Pendidikan Dasar Islam 6, no. 1 (2019): 7889.

Nurjannah, Mirna, Nurlili, and Andi Auliya Imunandar. "Analisis Kesalahan Siswa Dalam Memecahkan Masalah Pisa Ditinjau Dari Gender.” JTMT : Jurnal Tadris Matematika 1, no. 2 (2020): 1-8.

Murni Atma. "Pembelajaran Matematika Dengan Pendekatan Metakognitif Berbasis Masalah Kontekstual.” Pembelajaran Matematika Dengan Pendekatan....., no. November (2010): 518-27.

Zubaidah, Amir. "Strategi Metakognitif Dalam Pembelajaran Matematika." Jurnal Penelitian Dan Pembelajaran Matematika 10, no. 1 (2017). 
https://doi.org/10.30870/jppm.v10i1.1198. 